\title{
Problematika literarnozgodovinske umestitve Kafkovih besedil
}

Ključne besede: Franz Kafka, literarnozgodovinska umestitev, ekspresionizem, moderna, postmoderna, interpretacije Kafkovih literarnih besedil

DOI: $10.4312 /$ ars.9.2.144-157

Pričujoča raziskava je usmerjena na izpostavljanje in definiranje problemov, ki nastajajo pri literarnozgodovinskem umeščanju Kafkovih literarnih besedil.

Analize in interpretacije literarnih besedil Franza Kafke se mnogokrat končajo z zatekanjem avtorjev $\mathrm{k}$ historičnemu kriteriju (to je k dejstvom iz pisateljevega življenja), ki se vedno znova izkazuje za edino nesporno izhodišče pri analizi njegovih besedil. Zdi se, da poskusi dekodiranja Kafkovih tekstov literarne zgodovinarje večinoma pripeljejo do resignacije ali izgube literarnozgodovinske orientacije. Situacija je podobna pri literarnozgodovinskem umeščanju pisatelja: večpomenskost Kafkovih besedil povzroča literarnim zgodovinarjem številne težave, kot da se v množici slogovnih značilnosti ne bi mogli odločiti za prevladujočo.

Namen raziskave je pokazati, kako večpomenskost Kafkovih besedil vpliva na literarnozgodovinsko umeščanje pisatelja.

Glavni cilj raziskave je predstaviti rezultate analize izbranega korpusa z vidika literarnozgodovinskega umeščanja, zato je bil osnovni kriterij pri oblikovanju korpusa razvidnost problematike $\mathrm{v}$ analiziranih besedilih. Ta obsega temeljne nemške literarne zgodovine in leksikone avtorjev nemške književnosti ter interpretacije Kafkovih besedil, poiskane na podlagi informacij iz nemške bibliografije med letoma 2005 in 2010.

\section{Nemške literarne zgodovine}

V desetih od trinajstih analiziranih nemških literarnih zgodovin je Kafka uvrščen v poglavje o ekspresionizmu. Seveda gre za različne variante, kot npr. Avantgarda in ekspresionizem (Bark, 1984, 149), Prodor moderne: ekspresionizem (Leiß, 1997, 334), Ekspresionizem in njegove ekstremne pozicije (Geerds, 1967, 504), Od ekspresionizma do sodobnosti (Martini, 1958, 573-574), Ekspresionizem kot dominanta (Žmegač, 1980, 460) ali Ekspresionizem in sorodna gibanja (Žmegač, 1984, 310), vendar ostaja 
ekspresionizem vodilni termin. Iz navedenih naslovov lahko sklepamo, da uvrstitev Kafke v ekspresionizem le delno zajema bistvene poteze njegovega pisanja. Dopolnjujoči pojmi, kot npr. »moderna«, »avantgarda«, »ekstremne pozicije« ali »sodobnost«, nakazujejo potrebo po večji fleksibilnosti pri obravnavanju te problematike.

Prav to se potrdi pri branju argumentov v literarnih zgodovinah. Avtorji navajajo številne termine, ki nimajo nobene zveze z ekspresionizmom, svoje odločitve večinoma utemeljujejo s historičnimi dejstvi (Kafka je živel in ustvarjal v času ekspresionizma) in večinoma navajajo argumente, ki pisatelja ločujejo od ekspresionistov. Tako lahko v Zgodovini nemške literature J. Barka preberemo, da je "v času ekspresionizma v Pragi pisal prozo neki judovski pisatelj, ki stilistično ni pripadal nobeni določeni smeri«, in da je "postal moderni klasik, skozi katerega se je kazala kriza pripovedi kot začetek moderne literature (Bark, 1984, 149). Za E. Brennerja je Kafka »predhodnik nadrealizma«, ki je »bil velik zgled francoskim in ameriškim nadrealistom « (Brenner, 1956, 218). Tudi H. J. Geerdts opaža, da je bilo Kafkovo delo, ki je »mistifikacija pisateljeve najgloblje krizno občutene kapitalistične realnosti«, ki »vodi v nerazrešljivo nasprotje med kritiko in poabsolutenjem družbene stvarnosti«, kasneje označeno kot nadrealistično. To je »objektivno historični dekadentni osnovni značaj njegovega dela, ki vključuje tako nasilni radikalni poetični protest proti materialnemu značaju kapitalistične družbe kot mistifikacijo vseh socialnih pojavov« (Geerdts, 1967, 504). Ingo Leiß in Hermann Stadler ugotavljata, da »Kafkova prozna dela spadajo v moderno « in da je pisatelj »svoje like potisnil na meje človeških izkustvenih in spoznavnih zmožnosti« (Leiß, 1997, 334). Prepričana sta, da je najjasnejša značilnost Kafkovega dela večpomenskost. V literarni zgodovini F. Martinija beremo: »Odkril ga je evropski nadrealizem in strastno razpravljal o njegovi aktualnosti«, in dalje, da "gre pri Kafki za magični realizem«. Martini magični realizem utemeljuje z "grotesknim humorjem, pomešanim $\mathrm{z}$ obremenjujočo resnostjo, igrivo fantastiko, prepleteno z intelektualno napeto dialektiko, s sanjami in stvarnim naturalizmom «, vse to pa je "povezano v enovit stil«. Ta proza je po Martiniju dokument izgubljenosti, »najskrajnejša konsekvenca nihilizma, ki pri Kafki izzveni v zavest o smrti« (Martini, 1958, 573-574). Karl Propst v svoji Zgodovini nemške književnosti ugotavlja, da "Kafkovega dela, ki je izjemno pomembno za razvoj moderne pripovedne proze, skorajda ni mogoče literarnozgodovinsko umestiti, ker je bil pisatelj tipičen posebnež«. Tako »ležijo korenine njegovega magičnega realizma, posebne prepletenosti zasukane fantastike in grotesknega humorja, navsezadnje samo v njegovem bistvu in njegovi življenjski usodi« (Propst, 1974, 155). Kurt Rothmann pa poudarja, da »se v Kafkovih delih vedno znova pojavlja stilizirana biografska travma kot ponižno obnašanje nerazrešljivo premaganih junakov v boju z neoprijemljivimi silami«, bralec "gleda s Kafkovimi mikroskopskimi očmi skozi vedno znova trpeče junake iz nepregledne 
bližine. Vprašljive podrobnosti te perspektive mu zastirajo pogled na pregledno celoto« (Rothmann, 2001, 243). Viktor Žmegač trdi, da je »glede na recepcijo Kafka, ki je zaslovel šele dolgo po svoji smrti, avtor dvajsetih in tridesetih let, glede na svetovno razširjenost njegovih literarnih del pa avtor obdobja po letu 1945«. Nato dodaja, »da lahko Kafkovo delo v našem zgodovinskem kontekstu razumemo kot šifro za odtujene, do absurdnega roba potisnjene realne odnose. Kafkova vloga je za razvoj moderne proze v velikih svetovnih literaturah izjemno pomembna« (Žmegač, 1980, 460).

Lahko bi trdili, da večina zgoraj navedenih utemeljitev nima nobene zveze z ekspresionizmom in da v naslovih poudarjeni pojem »ekspresionizem « vzbuja ironijo, groteskni humor, ki je zelo podoben tistemu iz Kafkovih literarnih del. Pisatelj je označen s pojmi, kot npr. »moderni klasik«, "predhodnik nadrealizma«, "velik zgled francoskih in ameriških nadrealistov«, "tipičen posebnež«, "avtor dvajsetih in tridesetih let«, "avtor obdobja po letu 1945«. Samo v enem primeru je brez pridržkov uvrščen med ekspresioniste (Rothmann, 2001, 243). Na tem mestu se poraja vprašanje, zakaj je kljub vsem argumentom, ki govorijo proti njegovi uvrstitvi v poglavje o ekspresionizmu, Kafka vendarle večinoma umeščen prav tja. Lahko bi rekli, da so argumenti, ki potrjujejo literarnozgodovinsko umestitev v ekspresionizem, neprepričljivi ali celo napačno utemeljeni. Pri branju dobimo vtis, da so se avtorji za uvrstitev pisatelja $\mathrm{v}$ to poglavje odločili samo zato, ker so ga preprosto nekam morali umestiti. Ker večina izjav v argumentacijah omejuje ali celo negira odločitve za poglavje o ekspresionizmu, so se literarni zgodovinarji odločili za upoštevanje historičnega kriterija, kot npr. »Kafkova proza je presegala ekspresionizem « (Martini, 1958, 573), "Kafko lahko le delno razumemo kot ekspresionista« (Pochlatko, 1984, 241) ali »od ekspresionizma je sprejemal pomembne spodbude, vendar pa ta ne predstavlja bistva njegovega ustvarjanja» (Propst, 1974, 155) in "Kafko lahko le pogojno uvrstimo v krog ekspresionistične proze« (Žmegač, 1980, 461). Nihče namreč ne more oporekati dejstvu, da je pisatelj živel in ustvarjal v času ekspresionizma, ter domnevi, da je ta skoraj zagotovo vplival tudi na njegovo literarno ustvarjanje: »Kafka je ekspresionistični pisatelj praškega kroga in ga uvrščamo v tako imenovano praško šolo. Iz posebne situacije tega mesta je mogoče razložiti njegovo ekspresionistično držo« (Pochlatko, 1984, 241).

Kafkova večpomenska besedila na vsak način ponujajo različne možnosti pri obravnavanju problematike literarnozgodovinskega umeščanja, kar pa literarnim zgodovinarjem predstavlja veliko težavo, saj se v množici slogovnih značilnosti težko odločijo za prevladujočo.

Wilhelm Bortenschlager Kafko uvršča v poglavje Nadrealizem, svojo odločitev pa utemeljuje takole: [...] bivanje sodobnega človeka je predstavljeno kot absurdno 
in demonično [...], svet je brez smisla in nerazumljiv«, predvsem pa je »človeško bivanje določeno z vdorom neke tuje, anonimne sile. Pred premočjo tega tujega sveta je človek nemočen. Odtujenost med jazom in svetom je pripeljana do skrajnosti« (Bortenschlager, 1978, 49). Dodaja pa še, da je bilo Kafkovo delo zelo različno razlagano, kot npr. ekspresionistično, eksistencialistično, nadrealistično, mistično in psihoanalitično. Tako bralca opozarja, da je njegova umestitev samo ena izmed obstoječih možnosti.

V Novi nemški literarni zgodovini Petra J. Brennerja Kafko najdemo v poglavju Moderna. »Njegov izstopajoči pomen $\mathrm{v}$ literarni zgodovini je $\mathrm{v}$ tem, da je zavračanje smisla dosegel s sredstvi evropske pripovedne tradicije. Dualizem formalne konvencionalnosti in semantične radikalnosti je samo njegova posebnost, ki mu je prinesla enormen vpliv v literarni in duhovni zgodovini 20. stoletja. Kafka ustvarja svojo varianto fundamentalne krize zavesti moderne. « Avtor poudarja, da »zavzema delo Franza Kafke posebno mesto ne samo v literaturi njegovega časa, ampak tudi v sodobni evropski literaturi«. Dodaja še, da »je Kafka eden izmed redkih avtorjev, katerih ime je lahko postalo adjektiv, ki označuje ne samo neko literarno formo, ampak tudi neko stanje sveta: 'kafkovski' je postal sinonim za družbeno resničnost, ki se zapira vsakemu poskusu iskanja smisla in razlage« (Brenner, 1996, 218).

Literarnozgodovinska umestitev Kafke v Metzlerjevi Zgodovini nemške književnosti je recepcijsko usmerjena: »[...] Kafka je postal širše prepoznaven šele po prezgodnji smrti leta 1924, ko je njegov prijatelj Max Brod objavil njegove rokopise« (Stephan, 2001, 409). Iz navedenega razloga je pisatelj uvrščen v poglavje Literatura v Weimarski republiki. Avtorica nato navaja argumente, zaradi katerih pisatelja ni uvrstila med ekspresioniste, pri čemer poudari razliko prikazovanja generacijskega konflikta med očeti in sinovi pri Kafki in ekspresionistih. Po Stephanovi je posebna vloga in kvaliteta Kafke v nasprotju z ekspresionističnimi avtorji v tem, da zgoraj omenjenega konflikta ne prikazuje v smislu velikega patosa in psevdorevolucionarnosti, ampak pripomore $\mathrm{k}$ njegovemu razumevanju, saj njegove deformirajoče učinke na posameznika prikazuje $s$ točnostjo psihograma in tako bralcu ponuja možnosti za analizo.

Tudi v zadnjih treh primerih se ponovi že prej izpostavljeni vzorec argumentiranja: utemeljitve literarnih zgodovinarjev glede odločitev so neprepričljive in v nekaterih primerih nejasno formulirane. Čeprav je na prvi pogled morda videti drugače, pa so si vse literarnozgodovinske umestitve zelo podobne. Gre za medsebojno dopolnjevanje in izmenjavo pojmov »ekspresionizem «, »nadrealizem «, »moderna « in »literatura v Weimarski republiki«. Vprašanje dominance je prepuščeno odločitvam avtorjev literarnih zgodovin. Če je naslov npr. Ekspresionizem, potem so pojmi »nadrealizem«, 
»moderna« in »literatura v Weimarski republiki« v tekstu vključeni med argumente. Če pa se naslov glasi Moderna, lahko v besedilu najdemo pojme »ekspresionizem«, $»$ nadrealizem $« . .$.

Kot je bilo že ugotovljeno, je Kafkovo ustvarjanje močno zaznamovano z večpomenskostjo, kar literarnim zgodovinarjem ponuja različne možnosti in povzroča številne težave pri literarnozgodovinskem umeščanju pisatelja.

\section{Rezultati analize $v$ diagramih}

Diagrami prikazujejo rezultate analize iz prejšnjega poglavja.

1. Prva preglednica prikazuje literarnozgodovinsko umestitev Kafke v trinajstih analiziranih literarnih zgodovinah. Če upoštevamo naslove, lahko brez dvoma trdimo, da je bil Kafka ekspresionist. Vendar to ne drži, saj nadaljnje argumentacije prinašajo vse kaj drugega kot potrditev v naslovih navedene umestitve.

Preglednica 1: Literarnozgodovinska umestitev Kafke v nemških literarnih zgodovinah.

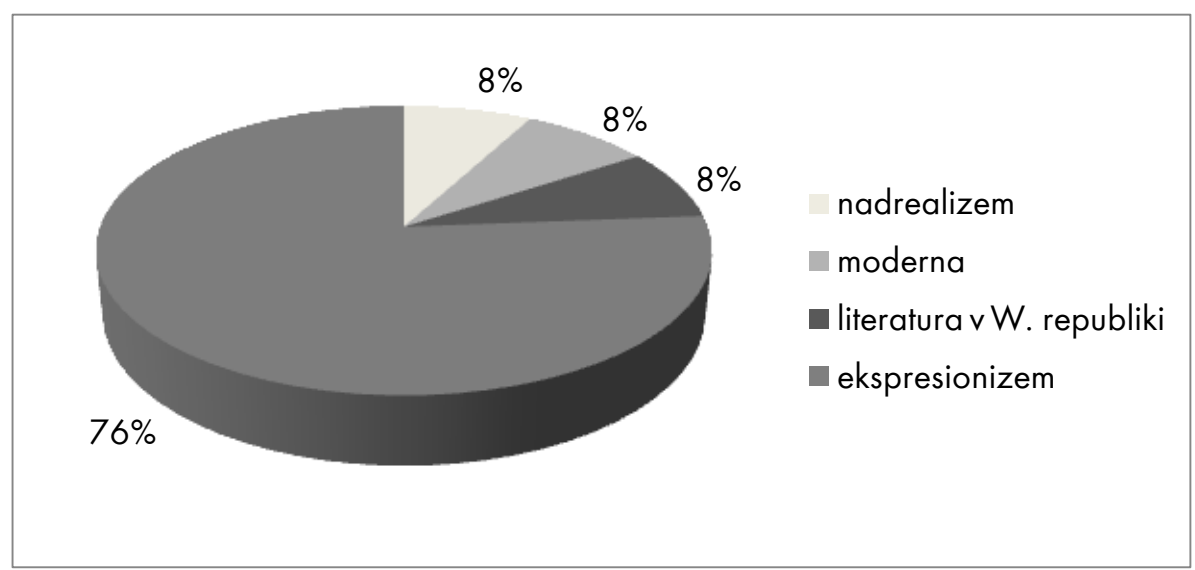

2. Naslednji diagrami ponazarjajo medsebojno dopolnjevanje literarnozgodovinskih pojmov pri umeščanju pisatelja v literarnih zgodovinah. $\mathrm{V}$ oklepajih so navedeni pojmi, ki v argumentacijah niso eksplicitno omenjeni, ampak samo opisani s tipičnimi značilnostmi. Črno obkroženi pojmi predstavljajo naslove, sivo obkrožene pa lahko najdemo v besedilu med utemeljitvami. 

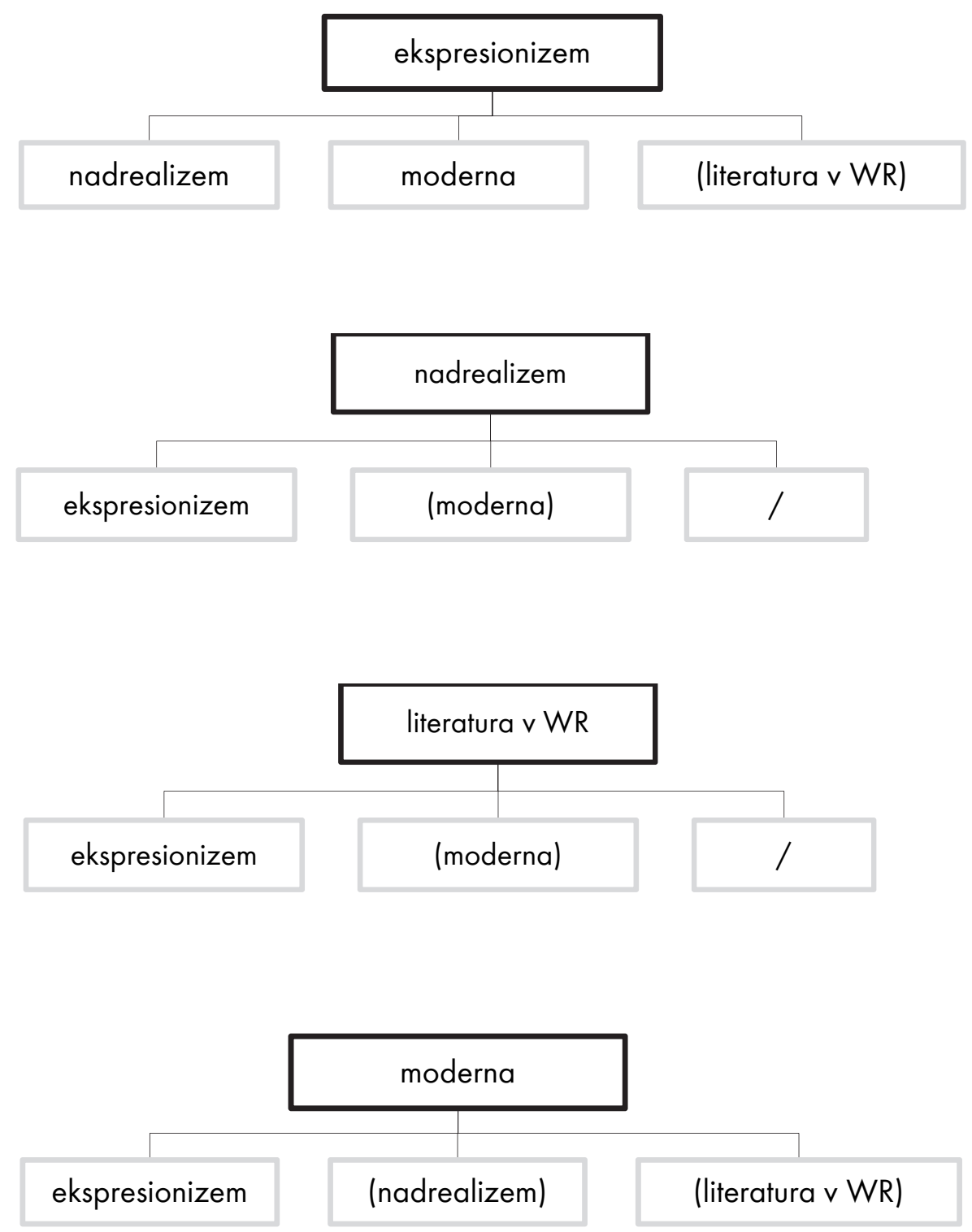

3. Na koncu je bila raziskana frekvenca literarnozgodovinskih pojmov, ki so se najpogosteje pojavljali $\mathrm{v}$ argumentacijah literarnih zgodovinarjev. Pojme sem preštela in uvrstila $\mathrm{v}$ diagram. Namen tega prikaza je pokazati, da pri literarnozgodovinskem umeščanju Kafke pomembno vlogo igra vsaj pet literarnozgodovinskih pojmov in da je zelo težko določiti najpomembnejšega. 
Preglednica 2: Frekvenca literarnozgodovinskih pojmov v nemških literarnih zgodovinah.

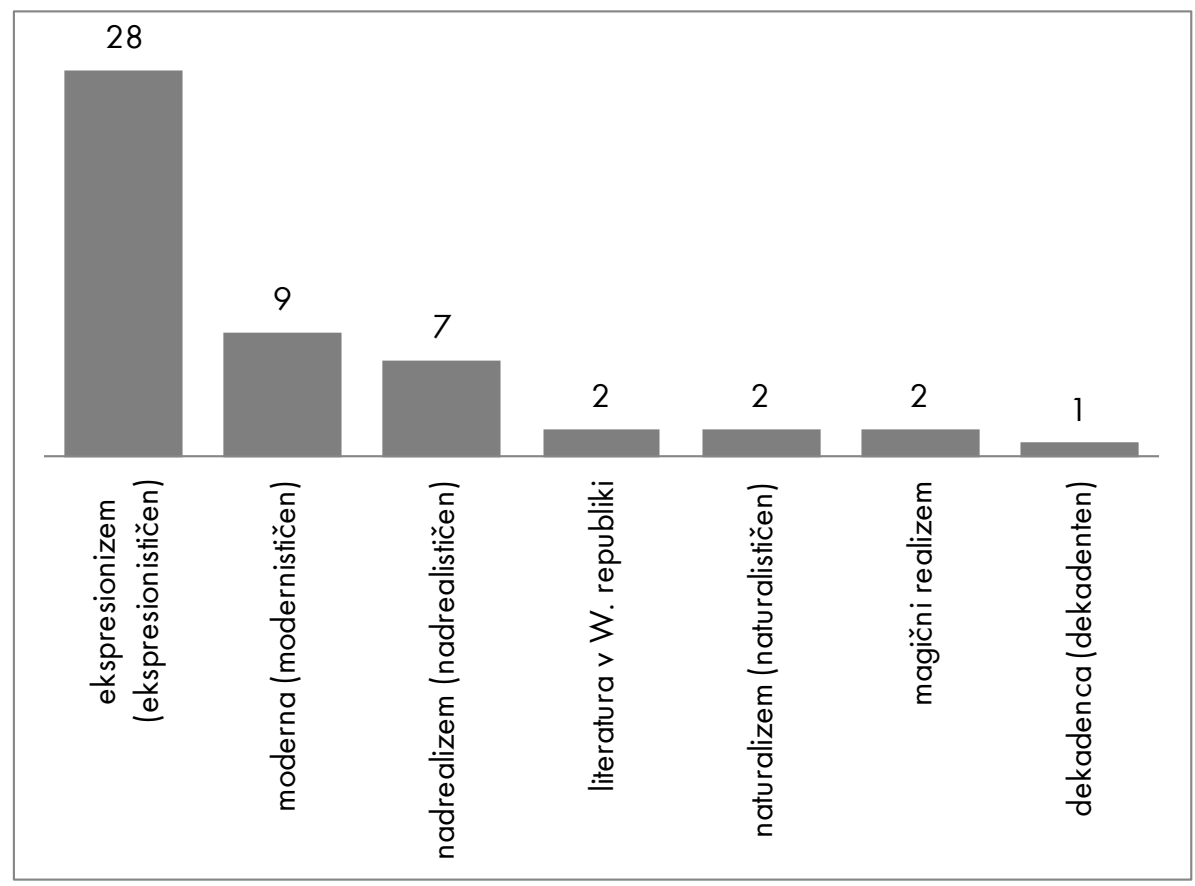

\section{Leksikoni avtorjev nemške književnosti}

Situacija glede literarnozgodovinske umestitve v leksikonih avtorjev nemške književnosti je primerljiva $s$ tisto $\mathrm{v}$ literarnih zgodovinah: tudi tu avtorji navajajo literarnozgodovinske pojme, ki jih pomanjkljivo ali pa sploh ne utemeljijo ali razložijo. Izkoriščajo namreč dejstvo, da je treba v leksikonih informacije samo navajati in da za temeljito literarnozgodovinsko argumentiranje ni prostora. Analizirali smo pet referenčnih leksikonov, $\mathrm{v}$ katerih je literarnozgodovinska umestitev pisatelja eksplicitno opredeljena.

V Leksikonu nemško govorečih pisateljev lahko preberemo, da »je pasivno, $\mathrm{z}$ nemočno in brezupno resignacijo napolnjeno občutenje sveta osnovni element njegovega [Kafkovega], pogosto kot 'nadrealistično' označenega pripovednega dela«. Sledijo argumenti: "groteskno-grozljiva snov«, »vizionarski in sanjski procesi znotraj (bolj ali manj) realnega dogajanja«. Nato avtorji razlagajo, da je bil Kafka "postavljen v službo modernističnih poznomeščanskih ideologij (nihilizem, eksistencializem) in da so ga revizionisti uporabili za izhodišče pri svojem napadu na socialni realizem« (Albrecht, 1972, 434-435). 
Manfred Brauneck se stvari loti drugače - predstavi celotno zgodovino recepcije Kafkovih del. Med drugim pojasni, da so »v Franciji najprej nadrealisti in pozneje eksistencialisti v Kafki prepoznali enega svojih" in da »so preučevali predvsem aspekte 'strahu' $\mathrm{v}$ Kafkovih delih ter jih primerjali s Sartrejevim in Camusovim 'ničem' in 'absurdnim'«. Tudi on omenja »socialno-kritično-filozofske interpretacije, ki izpostavljajo 'odtujeno subjektivnost' (Th. W. Adorno) ali kažejo na delu imanentno kritiko moderne industrijske družbe (W. Emrich)«. V razlagi najdemo še termin »dekadenca", in sicer v naslednjem smislu: »G. Lukàcs končno postavi 'življenjski kritični realizem' Th. Manna nasproti Kafkovi 'artistično zanimivi dekadenci' « (Brauneck, 1984, 313-314).

V Metzlerjevem Leksikonu nemško govorečih pesnikov in pisateljev najdemo zgodovinsko orientirano argumentacijo Kafkove umestitve v ekspresionizem, ki pa ji izdajatelji s precej neprepričljivimi argumenti oporekajo: »Wolf je vztrajno zbiral najpomembnejše, od leta 1914 kot 'ekspresioniste' označene mlade avtorje; tudi Kafka, čigar knjige so izhajale pri njem, je bil zato mnogokrat pomotoma razumljen kot ekspresionist.« Dodajo še, da nekatere pripovedi (Sodba, Preobrazba, Kurjač) »seveda na zelo poseben način variirajo takrat kot ekspresionistično občuteno temo konflikta med očetom in sinom « (Jeßing, 2004, 387-388).

Volker Meid izpostavi odtujenost človeka v modernem svetu, ki je ena osnovnih značilnosti Kafkovega ustvarjanja: »Osnovna izkušnja odtujenosti v svetu labirintov oziroma v 'kafkovskem' svetu najde svoj izraz v družbenem okvirju, med drugim v institucijah sodstva, birokracije in moderne tehnike (V kazenski koloniji, Proces, Grad)« (Meid, 2001, 461).

V Wikipediji lahko preberemo, da je »po mnenju Nabokova na Kafkovo literarno ustvarjanje najbolj vplival Flaubert«, da je Kafka »jezik uporabljal kot orodje« in da »je stil tisti, ki Kafko najbolj ločuje od ekspresionistov, saj je najbolj neverjetna stanja opisoval na najbolj jasen in stvaren način«. Stil je po Wikipediji tudi odgovoren za to, da »je Kafka ustvaril svoj svet z lastnimi zakoni, katerega unikatnost se navsezadnje potrjuje z vzpostavitvijo pojma 'kafkovski' (http://de.wikipedia, 2010).

Iz navedenega lahko povzamemo, da $\mathrm{v}$ nasprotju $\mathrm{z}$ analiziranimi literarnimi zgodovinami, kjer je Kafka v večini primerov umeščen $v$ obdobje ekspresionizma in se avtorji večinoma orientirajo po historičnem kriteriju, v leksikonih avtorjev nemške književnosti vlada zmešnjava. Avtorji sicer iščejo oprijemljivo izhodišče, vendar se izkaže, da pri umeščanju pisatelja razen zgodovinskega kriterija ne najdejo nobene druge oprijemljive točke. Glede na razlage naj bi bil Kafka nadrealist, eksistencialist, ekspresionist, modernist in avtor dekadence. V petih leksikonih avtorjev nemške književnosti lahko najdemo pet različnih literarnozgodovinskih umestitev pisatelja. 


\section{Interpretacije in analize Kafkovih literarnih besedil}

V obsežni množici interpretacij in literarnih analiz Kafkovih besedil jih zelo malo obravnava problematiko literarnozgodovinske umestitve pisatelja. Predvsem gre za novejša besedila $(2007,2008)$.

V nasprotju z nemškimi literarnimi zgodovinami in leksikoni avtorjev nemške književnosti avtorji interpretacij in analiz uporabljajo jasno in znanstveno podprto argumentiranje, kar je mogoče pripisati predvsem značaju interpretacij in literarnih analiz (argumentiranje, razlage, dokazovanje ...).

Thomas Anz (2008, 139-154) poudarja, da »so se pomembni pisatelji moderne distancirali od tradicionalnih podob, ki so umetnika stilizirale v genija, preroka, vodjo, kralja ali bogu enakega ustvarjalca«, in da »je Döblina v destrukciji tradicionalnih podob junakov in umetnikov v radikalnosti presegel samo en avtor moderne: Franz Kafka". Navedene izjave argumentira takole: »V Kafkovih zgodbah protagonisti ne rastejo in se ne razvijajo, ampak postajajo vedno manjši, vedno neznatnejši, šibkejši, vedno bolj neuspešni, tonejo vedno globlje.« Kafka je »umetnik pretiravanja in njegova umetnost pretiravanja [...] je navsezadnje umetnost pomanjševanja njegovih protagonistov. Pri tem prične $s$ povečavo kontrastnih figur, ki $\mathrm{v}$ tekstu fungirajo kot antagonisti." Avtor dodaja, da "je bilo razlikovanje med živaljo in človekom humanizmu skoraj najbolj sveta stvar. Spodkopavanje tega razlikovanja je spadalo $\mathrm{v}$ repertoar tistih tehnik šokiranja in provociranja, $s$ katerimi se je modernistična estetika profilirala nasproti klasični estetiki. Spadalo pa je tudi med tehnike, ki jih je uporabljal Kafka za destrukcijo tradicionalnih podob junakov in pisateljev, s tem pa tudi za pomanjševanje samega sebe« (Anz, 2008, 139-154).

Tudi Marie Haller-Nevermann in Dieter Rehwinkel Kafko umeščata med moderniste. Nato navajata argumente: $» \mathrm{~V}$ svoji kritiki institucij prikazuje brezizhodnost in resignacijo, izročenost na milost in nemilost ter brezup posameznika. [...] Dekonstrukcija tradicionalnih podob junakov in umetnikov je v svoji modernosti in radikalnosti prignana tako daleč, da je nadaljnje reduciranje komaj še mogoče.» Njegovi junaki »so zaznamovani $\mathrm{z}$ ambivalenco in šibkostjo, $\mathrm{z}$ občutkom socialne manjvrednosti, socialnega neuspeha, $\mathrm{z}$ nesposobnostjo partnerske navezanosti, poroke in potrditve potomcev, z eksistencialnim strahom in brezizhodnostjo« (HallerNevermann, 2008, 139-154).

Analiza Gerharda Riecka je koncipirana kot konfrontacija argumentov, ki naj bi Kafko opredelili kot modernista oziroma postmodernista. Avtor trdi, da je Kafka predstavnik moderne, svojo trditev pa utemeljuje takole: »To je sicer Kafkova notranja 'realnost fantazije' [...], vendar lepo demonstrira konstruktivni 'dekonstruktivizem' 
moderne: Psihoanaliza mogoče dekonstruira 'realnost', vendar z namenom, da bi v drugem koraku pokazala novo, drugačno realnost, medtem ko destruktivni dekonstruktivizem postmoderne proces dekonstrukcije realnosti razume kot neskončen proces brez rekonstrukcije« (Rieck, 2002, 36-55).

Bernd Neumann pojasnjuje, da »je prav postmoderna uživala Kafko kot svojo najljubšo jed « in da so njeni predstavniki »Kafkove tekste razumeli kot skrajne eksperimente $\mathrm{v}$ pripovedništvu sploh. [...] Kafkovo pisanje so razglašali za 'ilegitimno in anarhistično igro poetičnega govora’." Postmoderniste je fascinirala nerazložljivost Kafkovih besedil, še posebno njegov Pred zakonom: »Pred zakonom tematizira nerazložljivost vseh tekstov: Stojimo pred njim in ne moremo noter. Svetilnikov ni več, ampak samo zaslepljujoč ognjemet postmoderne igrivosti: dobro za zabavo, vendar v vsakem primeru slabo za orientacijo« (Neumann, 2007, 59-78).

Iz navedenega lahko zaključimo, da $\mathrm{v}$ interpretacijah in besedilnih analizah prevladuje literarnozgodovinska opredelitev Kafke kot modernista, nekateri pa ga razglašajo celo za postmodernista. Naj poudarimo še, da se interpretacije in literarne analize Kafkovih tekstov samo izjemoma ukvarjajo s to problematiko, saj mi je v izbranem korpusu interpretacij uspelo najti samo štiri primere.

\section{Zaključek}

Večina avtorjev v nemških literarnih zgodovinah in leksikonih avtorjev nemške književnosti je pri soočanju s problematiko literarnozgodovinskega umeščanja Franza Kafke dezorientirana, zato navajajo različne možne rešitve in več literarnozgodovinskih pojmov, ki naj bi označevali Kafkovo literarno ustvarjanje.

Zaradi zgoraj navedenih razlogov večina avtorjev nemških literarnih zgodovin upošteva historični kriterij in pisatelja umešča v ekspresionizem.

Situacija je drugačna pri analizah in interpretacijah Kafkovih besedil, ki se sicer samo izjemoma ukvarjajo $\mathrm{s}$ to problematiko, vendar je $\mathrm{v}$ njih literarnozgodovinska umestitev pisatelja podana $\mathrm{z}$ jasnimi, preglednimi in znanstveno utemeljenimi argumenti ter podprta $\mathrm{z}$ ustreznimi citati. V treh primerih od štirih analiziranih je Kafka uvrščen med moderniste, v enem pa ga avtor razglaša celo za postmodernista.

Glede na sodobne razprave spada Kafka med moderniste, čeprav ta umestitev ne zajema bistva njegovega pisanja v celoti. Popolnoma ustrezno ga opredeljuje samo termin »kafkovski«, ki zajema vse značilnosti njegovega pisanja, hkrati pa označuje literarno realnost v Kafkovih delih, ki je unikatna in odraža zmožnost literature, da 
lahko z izkoriščanjem kompleksnosti svojega lastnega jezika pokaže našo nekognitivno pozicijo nasproti nespoznavnemu.

\section{Viri in literatura}

Albrecht, G. in drugi, Lexikon deutschsprachiger Schriftsteller. Von den Anfängen bis zur Gegenwart, Leipzig 1972.

Anz, T., Kafkas Helden der Moderne, v: Franz Kafka - Visionär der Moderne (ur. Haller-Nevermann, M. in drugi), Göttingen 2008, str. 139-154.

Bark, J. in drugi, Geschichte der deutschen Literatur. Vom Naturalismus zum Expressionismus. Literatur des Kaiserreichs, Stuttgart 1984.

Beutin, W. in drugi, Deutsche Literaturgeschichte. Von den Anfängen bis zur Gegenwart, Stuttgart, Weimar 2001.

Bortenschlager, W., Deutsche Literaturgeschichte. Vom ersten Weltkrieg bis zur Gegenwart (Neuauflage der deutschen Literaturgeschichte von E. Brenner), Dunaj 1978.

Brauneck, M., Autorenlexikon Deutschsprachiger Literatur des 20. Jahrhunderts, Reinbek bei Hamburg 1984.

Brenner, E., Deutsche Literaturgeschichte, Wunsiedel, Wels, Bad Reichenhall 1956.

Brenner, P. J., Neue deutsche Literaturgeschichte, Tübingen 1996.

Burdorf, D. in drugi, Metzler Lexikon Literatur. Begründet von Günther und Irmgard Schweikle, Stuttgart, Weimar 2007.

Culler, J., On Deconstruction: Theory and Criticism after Structuralism, Ithaca, New York 1986.

Deleuze, G. in drugi, Kafka für eine kleine Literatur, Frankfurt na Majni 1976.

Geerdts, H. J., Deutsche Literaturgeschichte in einem Band, Berlin 1967.

Haller-Nevermann, M. in drugi, Franz Kafka - die Visionen des Prager Dichters heute, v: Franz Kafka - Visionär der Moderne (ur. Haller-Nevermann, M. in drugi), Göttingen 2008, str. 7-13.

Hiebel, H. H., »Später!« - Poststrukturalistische Lektüre der »Legende« Vor dem Gesetz, v: Bogdal, K. M. (Hrsg.), Neue Literaturtheorien in der Praxis. Textanalysen von Kafkas Vor dem Gesetz (ur. Bogdal, K. M.), Opladen 1993, str. 18-42.

Jahraus, O. in drugi, Kafkas »Urteil« und die Literaturtheorie: Zehn Modellanalysen. Stuttgart 2010.

Jeßing, B. in drugi, Metzler Autoren Lexikon. Deutschsprachige Dichter und Schriftsteller vom Mittelalter bis zur Gegenwart, Stuttgart, Weimar 2004. 
Leiß, I. in drugi, Deutsche Literaturgeschichte. Wege in die Moderne. 1890-1918, München 1997.

Martini, F., Deutsche Literaturgeschichte. Von den Anfängen bis zur Gegenwart, Stuttgart 1958.

Meid, V., Reclams Lexikon der deutschsprachigen Autoren, Stuttgart 2001.

Neumann, B., Die Postmoderne im Höhenrausch, oder: Derrida und Franz Kafkas Vor dem Gesetz, v: Moderne, Postmoderne und was noch? Akten der Tagung in Oslo, 25.-26. 11. 2004 (ur. Sagmo, I. in drugi), Frankfurt na Majni 2007, str. 59-78.

Pochlatko, H. in drugi, Einführung in die Literatur des deutschen Sprachraums von ihren Anfängen bis zur Gegenwart. Mit besonderer Berücksichtigung des österreichischen Schrifttums. 3. Teil, Dunaj 1984.

Propst, K., Geschichte der deutschen Literatur. 2. Band. Von 1848 bis zur Gegenwart, Dunaj 1974.

Rieck, G., Die Literaturwissenschaft als Schlossbürokratie, v: Franz Kafka und die Literaturwissenschaft (Rieck, G.), Würzburg 2002, str. 36-55.

Rothmann, K., Kleine Geschichte der deutschen Literatur, Stuttgart 2001.

Stephan, I., Literatur in der Weimarer Republik, v: Deutsche Literaturgeschichte. Von den Anfängen bis zur Gegenwart (ur. Beutin, W. in drugi), Stuttgart, Weimar 2001, str. 409.

Virk, T., Nedostopnost absolutnega, v: Proces (Franz Kafka), Ljubljana 1998, str. 215228.

Walser, M., Beschreibung einer Form: Versuch über Franz Kafka, München 1963.

Zima, P. V., Moderne/Postmoderne: Gesellschaft, Philosophie, Literatur, Tübingen, Basel 1997.

Žmegač, V., Geschichte der deutschen Literatur vom 18. Jahrhundert bis zur Gegenwart. Band II/2. 1848-1918, Königstein 1985.

Žmegač, V. in drugi, Kleine Geschichte der deutschen Literatur. Von den Anfängen bis zur Gegenwart, Königstein 1984.

\section{Elektronski viri}

http://de.wikipedia.org/wiki/Franz_Kafka [11. 2. 2010]. 


\section{Problematika literarnozgodovinske umestitve Kafkovih besedil}

Ključne besede: Franz Kafka, literarnozgodovinska umestitev, ekspresionizem, moderna, postmoderna, interpretacije Kafkovih literarnih besedil

Poskusi dekodiranja Kafkovih tekstov literarne zgodovinarje večinoma pripeljejo do resignacije ali izgube literarnozgodovinske orientacije. Situacija je podobna pri literarnozgodovinskem umeščanju pisatelja: večpomenskost Kafkovih besedil literarnim zgodovinarjem povzroča številne težave, kot da se v množici slogovnih značilnosti ne bi mogli odločiti za prevladujočo.

Namen raziskave je pokazati, kako večpomenskost Kafkovih besedil vpliva na literarnozgodovinsko umeščanje pisatelja.

S problematiko literarnozgodovinske umestitve Kafkovih del se ukvarjajo le redki leksikoni nemških literarnih avtorjev in interpretacije ali analize njegovih besedil. V interpretacijah in besedilnih analizah prevladuje literarnozgodovinska opredelitev Kafke kot modernista, nekateri avtorji pa ga razglašajo celo za postmodernista.

Avtorji nemških literarnih zgodovin in leksikonov nemških literarnih avtorjev so pri soočanju s to tematiko večinoma dezorientirani, zato navajajo več literarnozgodovinskih pojmov. Poleg umestitve Kafke v ekspresionizem ga hkrati opredeljujejo tudi kot nadrealista, eksistencialista ali pripadnika magičnega realizma. Zaradi navedenih razlogov se večina avtorjev nemških literarnih zgodovin odloča za upoštevanje historičnega kriterija in pisatelja umešča v ekspresionizem. 
Mateja Clara Jelenčič

\section{The Problems of the Literary-historical Classification of Kafka's Texts}

Keywords: Expressionism, literary-historical classification, Modernism, Postmodernism, interpretations and literature analyses

Attempts at the literary classification of Kafka's texts often prove to be problematic. Most authors are at a loss, so they propose more than classification.

The problem of the literary classification of Kafka's texts is treated only in a few German literary encyclopedias and in interpretations and analyses of his texts.

In the interpretations and literary analyses Kafka is mostly classified as a Modernist, but some authors see him as a Postmodernist.

Most German literary historians and encyclopedia writers are caught in a dilemma about this subject and so propose more than one literary classification: Kafka is assigned to Expressionism and also proclaimed as a representative of the Existentialism, Surrealism or Magic realism. However most German literary historians often assign Kafka to the Expressionism on historical grounds. 